\title{
Livros didáticos em dimensões materiais e simbólicas
}

\author{
Antonia Terra de Calazans Fernandes \\ UNIFIEO - Centro Universitário FIEO
}

\section{Resumo}

0 texto apresenta o relato de uma pesquisa em andamento sobre a memória de usuários de livros didáticos. As reflexões estão baseadas no trabalho de história oral, de coleta e análise de entrevistas com alunos e professores, que interagiram com esses materiais no espaço escolar, entre os anos de 1940 e 1970, e que são procedentes de diferentes localidades brasileiras. A proposta tem sido investigar as reminiscências do livro didático; quais têm sido aquelas que sinalizam suas interferências na formação social e cultural das pessoas e no seu imaginário; os papéis sociais, educacionais e culturais que o livro didático alcança na formação de gerações ou em localidades; e os valores atribuidos a esses objetos, que orientam, por exemplo, atitudes em prol de sua guarda ou preservação.

A pesquisa faz parte de um projeto maior, "Educação e memória: organização de acervo de livro didático”, coordenado pela professora Circe Bittencourt, na Faculdade de Educação da USP, do qual fazem parte pesquisadores que trabalham com diferentes problemáticas, variadas áreas de conhecimento e que utilizam fontes distintas. E, nesse sentido, o trabalho procura contribuir também para a identificação de dados que colaboram para ampliar o número de informações gerais que instiguem ou com-plementem outras pesquisas possíveis relativas a esse objeto de estudo.

\section{Palavras-chave}

Educação - Livro didático - Memória - História oral.

\section{Correspondência:}

Antonia Terra de Calazans Fernandes

Rua João Miguel Jarra, 135 - ap. 15

05417-040 - São Paulo - SP

e-mail: antoniaterra@uol.com.br 


\title{
Schoolbooks in their material and symbolic dimensions
}

Antonia Terra de Calazans Fernandes

UNIFIEO - Centro Universitário FIEO

\begin{abstract}
The text reports on an ongoing study about people's memories of schoolbooks. The reflections are based on oral histories and on the conduction and analysis of interviews with pupils and teachers from various places in Brazil, and which interacted with schoolbooks within the school environment between the 1940s and 1970s. The proposal has been to investigate the reminiscences of the schoolbook, which of them point to their influence in the social and cultural education of the users, as well as in the constitution of their imaginaries; the social, educational and cultural roles achieved by the schoolbook in the education of generations and/or localities; and finally the values attributed to those objects, which guide, for instance, attitudes towards their guard and preservation.

The present study is part of a larger project entitled "Education and memory: organization of collections of schoolbooks" coordinated by Dr Circe Bittencourt from the Faculty of Education, USP. That project has researchers working on different problems, from various fields of knowledge, and utilizing distinct sources in their work. In that sense, the present study seeks to contribute also to the identification of sources that may be of use in increasing the overall information available to foster or supplement other possible researches about this object of study.
\end{abstract}

\section{Keywords}

Education - Schoolbook - Memory - Oral history.

\section{Contact:}

Antonia Terra de Calazans Fernandes Rua João Miguel Jarra, 135 - ap. 15 05417-040 - São Paulo - SP

e-mail: antoniaterra@uol.com.br 
Dada a sua importância, o livro didático é um amplo campo de pesquisa. Para entendê-lo, na sua função educacional, sua história e sua presença entrelaçada na vida social brasileira, é necessário considerar diferentes campos de estudo e privilegiar uma diversidade de fontes. Entre as produções existentes, a maioria tem como base a análise do próprio livro e de seus conteúdos. Os estudos analisam, fundamentalmente, seus discursos textuais e iconográficos, e de que forma difundem conhecimentos científicos atualizados ou ultrapassados. Produções recentes, porém, têm diversificado temas e documentos, dando conta desde sua concepção, produção, difusão e uso, quanto de suas relações com as políticas públicas, os currículos escolares e a indústria editorial. Nessa linha, pesquisas a partir de fontes orais começam a contribuir também para ampliar a compreensão do papel histórico e social dos manuais escolares.

0 trabalho com depoimentos orais abre a perspectiva para aproximações com diferentes sujeitos históricos, de várias classes e vivências sociais, valorizando a diversidade e a subjetividade (Ferreira; Amado, 2002); e, ao mesmo tempo, na análise comparativa, indica pistas para padrões sociais e culturais comuns entre gerações, ao longo do tempo e por localidade. É por essas razões que para pesquisar a memória dos manuais escolares optamos por um trabalho com história oral, como orientam historiadores como Paul Thompson (1992) e Alessandro Portelli (1993). Se a pesquisa se detivesse nos materiais impressos, as memórias em estudo ficariam restritas às dos literatos e memorialistas, já analisados no caso do Brasil, por exemplo, por Circe Bittencourt (1993).

0 que se constata é que socialmente, do ponto de vista do usuário (alunos e professores), depois que deixa de ser utilizado como material na sala de aula, o livro didático, só em casos específicos, foi guardado, revisitado ou reencontrado com o passar do tempo. E, nessas situações, também cabe questionar sua mudança de valor com o tempo.
Quais têm sido os valores atribuídos aos livros didáticos em diferentes épocas? 0 que os usuários lembram desses materiais escolares? Quais imagens desses livros têm sido preservadas? Quais conteúdos? Quais identidades sociais eles têm contribuído para consolidar? Quais disciplinas estão a eles associadas? Quais vivências e experiências foram guardadas envolvendo seu uso na escola ou fora dela? 0 que os usuários lembram de como os livros eram utilizados? Os livros didáticos têm sido preservados por seus usuários? Por quê? Há padrões nacionais de livros, autores ou de uso desses materiais que a análise das memórias permite identificar?

Para responder a essas e outras perguntas temos entrevistado alunos e professores, a partir de fundamentos teóricos da história oral, que interagiram com esses materiais no espaço escolar entre os anos 1940 e 1970. Assim, inicialmente, estão sendo entrevistadas pessoas que viveram sua escolaridade ou lecionaram em diferentes épocas, com o objetivo de fazer um levantamento que possibilite, por exemplo, entrever indícios de fatores que interferem, em parte, na quantidade ou qualidade das memórias, ou seja, se a idade, se a geração, se o grau de escolaridade ou se o contexto da escolaridade interferem ou não nos depoimentos e nas lembranças sobre os livros. Inicialmente, a baliza de tempo da pesquisa abarcava as décadas de 1930 e 1960 . Mas, à medida que as entrevistas foram sendo feitas, o recorte temporal foi sendo ampliado porque constatamos que uma das pessoas entrevistadas, nascida na década de 1930, tinha poucas lembranças do livro didático. Passamos a entrevistar, então, pessoas nascidas também nas décadas de 1950 e 1960 (com escolaridade posterior) com a intenção de avaliar, por exemplo, a interferência da idade nas lembranças.

Até o momento, na medida em que privilegiamos a diversidade de idade, o que constatamos é que o que menos interfere na memória do livro didático é o fator idade. A análise das entrevistas tem indicado, até o 
momento, que quanto maior a escolaridade maior o número de lembranças sobre o tema, mesmo sendo o depoente mais velho. A pessoa entrevistada com menor escolaridade e, ao mesmo tempo, a de menor idade, é a que recordou menos dos livros, contou menos detalhes, levantou menos dados.

Além da baliza de tempo, outra variável na seleção dos entrevistados tem sido o local onde o depoente estudou ou lecionou, com o objetivo de identificar a presença de diferentes materiais e culturas escolares de acordo com a região do Brasil: se há padrões nacionais e se há produções e estudos especificamente locais.

Entre as entrevistas, para este artigo, salientamos depoimentos coletados com as seguintes pessoas e seus contextos escolares, sem contudo identificá-las nominalmente:

a) Entrevistado 1: ex-seminarista, nasceu em 1929, no sertão do Rio Grande do Norte, e mora hoje em São Paulo. Freqüentou durante dois anos o Grupo Escolar José Marcelino, na Vila de Vitória, que hoje é a cidade de Marcelino Vieira, no interior do Rio Grande do Norte. Freqüentou, na seqüência, como interno, o Seminário Santa Terezinha, de padres alemães e italianos, na cidade de Mossoró, entre os anos de 1939 e 1948. No seminário, viveu um ano de adaptação e fez dois anos de curso preliminar; cinco anos que corresponderiam ao ginásio e colégio, e dois anos de filosofia.

b) Entrevistado 2: nascido em 1930, em São Sebastião do Paraíso, Minas Gerais, mas que morou quando criança em Ribeirão Preto, São Paulo, e quando adolescente em Barretos, nesse mesmo estado, e em 1956 mudou-se para a capital. Em São Sebastião do Paraíso, na Escola Municipal Coronel Cândido (Grupo Escolar - primário); em Ribeirão Preto, freqüentou dois anos do ginásio na escola particular Lacerda Franco, e um ano no Colégio Estadual - artigo 91, e mais um ano de Madureza do ginásio, em 1952; depois, em 1953, colégio estadual; três anos na escola do
Senac - Técnico de vendas, 1955; Faculdade de Administração de Empresa, Colégio Brasil, de 1960 a 1964 (o colégio já foi fechado). Trabalhou desde a década de 1950, como faxineiro, vendedor, gerente de loja, vendedor farmacêutico. Hoje, aposentado, é síndico.

c) Entrevistado 3: nascida em São José do Rio Preto, em 1944. Estudou lá até os vinte anos, até ir completar seu curso de pedagogia em São Paulo. Hoje é professora universitária.

d) Entrevistado 4: nascida em 1955, em Osasco, São Paulo, onde mora até hoje. Estudou no primário em uma escola estadual, no Jardim das Flores, Escola La Torre (1965). No Ginásio, estudou na escola estadual Prof. João Larizatte, entre 1971 e 1973. Saiu da escola para casar, em 1974. Voltou a estudar depois dos filhos crescidos. Fez supletivo, depois a faculdade de Artes e agora está terminando a faculdade de História. Ela deu seu depoimento depois de ter encontrado seus antigos livros didáticos. Recorreu, então, aos livros para lembrar quando estudou e para contar outras histórias.

e) Entrevistado 5: nasceu em 1957, em Porto Alegre. Mudou-se para São Paulo em 1969. De 1964 a 1966, freqüentou, no primeiro ano, uma escola estadual, no primário. Quando foi morar com a tia, no bairro de Santana, em Porto Alegre, em 1967, passou a estudar no colégio estadual lldefonso Gomes, e aí fez o $1^{\circ}$ e o $2^{\circ}$ ano de uma só vez. Foi para São Paulo em 1969. Estudou no Colégio Estadual D. Pedro 11, na Barra Funda. Em 1970, estudou no Ginásio Manoel Bandeira. Fez o colegial - 1973 e 1974 - na Escola Estadual Maximiliano, na Vila Madalena. De 1975 a 1977, estudou no Colégio Pinheiros (particular). E fez cursinho no Equipe, em 1978. Em 1979, estudou Ciências Contábeis e depois Economia na PUC, até 1981.

f) Entrevistado 6: nascida em 1963, em Itambé, interior da Bahia. Residente hoje em São Paulo. Estudou em escolas de fazendas, até a $5^{\text {a }}$ série (Escola Municipal de ltambé). Depois mudou para Vitória da Conquista/ BA. 
Da perspectiva do procedimento de coleta de entrevistas, lembramos, como em outros trabalhos que utilizam a metodologia de história oral, que "os depoimentos coletados poderiam ter sido outros, se tivessem acontecido em outros contextos" (Fernandes, 1997). 0 fato de informar ao depoente, antes de cada entrevista, as intenções da pesquisa, ele acaba se orientando, de certo modo, a escolher o que falar e como falar.

Como já pontuamos em outro artigo, entendemos livro didático numa perspectiva ampla, isto é,

como publicações diversas, utilizadas em situações escolares por professores e/ou alunos para orientação, estudo, leitura e exercicios: compêndios, cartilhas, livros literários, paradidáticos, manuais de orientação para o docente, cadernos de desenho, tabuadas e coletânea de mapas. (Fernandes, 2002)

E entendemos memória como a

organização e o relato de lembranças acerca de informações, imagens, idéias, experiências, vivências, emoções e valores que foram selecionados, recriados, ressignificados e preservados por individuos ao longo do tempo. (Fernandes, 2002)

\section{Significados dos livros didáticos}

0 trabalho com história oral impõe ao historiador a coleta de depoimentos que suscitam memórias, as quais são narradas e organizadas em função de diferentes características que lhe são próprias. Uma das características da memória, que é essencial ao historiador, é o fato de, apesar de resguardar sua dimensão subjetiva, também expressar na sua constituição bases coletivas.

Não é suficiente reconstituir peça por peça a imagem de um acontecimento do passado para se obter uma lembrança. É necessário que esta reconstrução se opere a partir de dados ou de noções comuns que se encontram tanto no nosso espírito como no dos outros, porque elas passam incessantemente desses para aquele e reciprocamente, o que só é possível se fizeram e continuam a fazer parte de uma mesma sociedade. Somente assim podemos compreender que uma lembrança possa ser ao mesmo tempo reconhecida e reconstruída. (Halbawachs, 1990, p. 34)

Valores e experiências comuns a grupos e sociedades estão presentes, por exemplo, nos significados atribuídos aos indivíduos, aos acontecimentos e aos objetos que emergem nas memórias ou que são preservados como suportes de lembranças. Assim, cabe perguntar: por que alunos e professores preservam seus livros didáticos? Há valores sociais costurando suas memórias e orientando suas atitudes?

Coletamos o depoimento de uma professora que estudou nas décadas de 1950 e 1960, e que guardou seus manuais escolares como símbolo da importância da escola em sua vida e de sua família, e como elementos constituintes de uma identidade com determinado grupo social, de baixo poder aquisitivo e de pouca escolaridade, cujo acesso ao mundo letrado e literário foi por meio desses corriqueiros, mas antigamente tão preciosos, materiais didáticos:

“(...) e aí conforme os irmãos iam estudando também, se o livro era o mesmo usava o mesmo. Mas, às vezes, na outra escola um outro professor indicava outro livro e comprava outro livro e aí a gente foi formando uma pequena biblioteca na casa. Mas nunca era uma coisa assim, por exemplo, ter livros de literatura, por exemplo, a gente não tinha. Eu sempre tive muitos livros de... as Edições Maravilhosas, e livros didáticos... Porque o livro didático realmente pro pessoal que tinha, por exemplo, a condição social que eu tinha, era o contato com o 
mundo mesmo da literatura, da produção, porque não tinha essa facilidade, que nem hoje você vai dar um presente e escolhe um livro de poesia, vai escolher um romance bom, não tinha, não era assim. Era uma coisa bem mais restrita." (Entrevistado 3)

E hoje? E para outros grupos sociais? Cabe perguntar se atualmente e para quais grupos o livro didático tem tido semelhante valor? Será que as políticas públicas interferem no valor dado ao livro, já que nem sempre ele permanece com seus usuários além do período do ano letivo, considerando a prática de adotar livros não-consumíveis?

A história oral é um caminho potencial para suscitar e alimentar a memória do livro didático, indicando representações construídas pelos usuários no contexto de suas vivências; e fornecendo pistas de quais eram esses materiais, quais seus usos na escola e qual seu valor para indivíduos nas suas trajetórias sociais e para alunos e professores nas suas vivências educacionais.

No caso do trabalho de coleta de depoimentos referente à pesquisa em curso, uma outra entrevista exemplifica o processo de construção do valor atribuído ao livro. A depoente foi entrevistada na seguinte situação: o livro didático estava sendo estudado em sua faculdade e por isso ela foi solicitada a procurar seus antigos manuais para analisá-los em sala de aula. Por essa razão, vasculhou sótãos e encontrou livros do tempo em que freqüentou o antigo primário e o ginásio. Com os livros na mão, passou a lê-los e a recordar as vivências da escola. Passou, então, a avaliar a sua escolaridade e a recordar sua trajetória. Simultaneamente, descobriu em um livro do ginásio uma dedicatória do atual marido, que até então não tinha notado:

“(...) trouxe para casa, folheando ele, achei a dedicatória que meu marido havia feito para mim em 1973. Que eu tinha terminado o ginásio e ele vendo meus livros fez essa dedicató- ria (...) e eu não vi. Eu não... não sabia dessa dedicatória. Aí folheando o livro [L.G. Motta Carvalho, Ensino moderno de História do Brasil. Editora do Brasil S. A., 2º volume] em casa, eu achei. Aí mostrei pra ele. E falou: não acredito, você não viu isso? Falei: não vi! Fiquei emocionada, até chorei de verdade. Falando sinceramente... sinceramente agora para você. Falei 'nossa bem...' a gente se trata por bem, né... moda antiga ainda... Ele falou: "pois é, fui eu que fiz, na sala de sua casa e se você quiser eu faço a mesma dedicatória na outra página'. Eu fiquei mais feliz ainda.... E isso me incomodou bastante porque... pra mim o livro passou a ser valioso duas vezes: uma porque passou a ser um livro que eu estava precisando... tem coisa nele que eu precisava... três vezes até...; outra, lembrou bastante minha adolescência; e a terceira, mais importante, a dedicatória do meu marido, que eu fiquei bastante feliz com isso." (Entrevistado 4)

0 fato de ter recentemente recuperado seus livros didáticos contribuiu para valorizar esses objetos em seu depoimento e para descobrir um outro sentido, agora emocional, para preservá-los. Além disso, ter em mãos os livros mudou também o tipo de lembranças descritas. A depoente recordou com segurança os títulos, os autores, formatos, conteúdos e como era utilizado para estudo.

“No primário também, no primário você vendo o livro Alvorada [Antonio D’Ávila, Companhia Editora Nacional, 1965], você vê os conteúdos do livro. Lógico que tinha umas bobagenzinhas assim tipo da abelha, do macaco, a historinha meio que infantil. Mas tem um belo conteúdo, ensinando bastante coisa de português, coletivo... Estava vendo o livro, relendo o livro, e perguntava pro meu marido: você lembra do coletivo de...? Eu lembro, naquela época ficou bem marcado, a gente aprendeu muito bem. Os professores faziam questão da gente aprender e bem. Tanto é que nas férias não tinha folga não." (Entrevistado 4) 
Um depoimento como esse revela a particularidade da história oral em lidar com questões específicas da memória. Como se tem estudado, a memória é sempre uma construção e depende de uma seleção dos acontecimentos do passado e da criação de significados em função do contexto do presente. Assim, nos depoimentos podemos identificar valores atribuídos ao livro didático que marcaram a memória dos indivíduos no passado, como também valores que são impingidos a esses materiais no presente. Um e outro interferem nos acontecimentos narrados.

a lembrança é em larga medida uma reconstrução do passado com a ajuda de dados emprestados do presente, e, além disso, preparada por outras recordações feitas em épocas anteriores e de onde a imagem de outrora manifestou-se já bem alterada. (Halbwachs, 1990, p. 71)

Um outro exemplo dessa reconstrução da memória está nas lembranças de uma outra depoente. Para uma professora, que teve sua vida profissional organizada em função da escola, suas vivências como aluna, no tempo em que freqüentou o primário e o ginásio, ganharam aos poucos outros significados. Os mesmos livros da infância permaneceram em sua vida quando começou a lecionar, só que com outro uso, inseridos em outros contextos, avaliados a partir de outras perspectivas e narrados pela memória com sentidos e valores incorporados a eles com o tempo:

“Quando eu já estava na $3^{\mathrm{a}}$ ou $4^{\mathrm{a}}$ série, eu me lembro que algumas professoras da escola o utilizavam. Uma professora minha só, que acho que foi da $4^{\text {a }}$ série, utilizou esse livro. Ele tinha lições e exercícios de todas as matérias. (...) Era um brochurão assim e tinha todas as matérias em seqüência e tinha o texto da questão, pergunta, e espaço para você responder. E depois eu fui reencontrar como professora isso. (...) eu pro- fessora aqui em Osasco, na rede estadual, já tinha terminado a faculdade, fui encontrar muitos colegas se 'amuletando' mesmo nesse livro (...) se dispensando de preparar as coisas tal e aí lição tal, lição tal para casa, corrigir lá no próprio livro, então uma coisa assim que me dava arrepios, de ver assim como não deve ser usado mesmo, como uma muleta." (Entrevistado 3)

De modo geral, o livro didático tem sido desvalorizado depois de seu uso imediato por cumprir uma função específica na vida dos indivíduos, ou seja, por ser intrínseco ao contexto escolar, tornando-se descartável e sem valor fora de seu contexto original. Todavia, para uma pessoa que valoriza a educação, que tem sua vida profissional ligada ao magistério, o livro didático ganha em sua memória outra coloração. 0 valor atribuído ao livro e à leitura em geral estende-se também aos materiais didáticos:

"Eles são um símbolo assim. Eu espero que você receba com muito carinho os que eu te dei, porque eu não consegui me desfazer deles. E eu sempre fui muito mais generosa pra emprestar livro. Perdi mais de duzentos volumes só emprestando tudo. Mas aqueles que foram meus, lá do começo, já não têm serventia, ninguém dá valor pra eles e eu nunca quis pôr num sebo, nunca quis me desfazer deles assim... e... então é simbólico pra mim aquilo. Eu acho que foram um símbolo pra mim da escola que pra mim era tão importante, e o primeiro contato mesmo com as coisas escritas assim. E até hoje eu acho livro uma coisa, uma coisa muito importante mesmo, muito importante, porque é você jogar semente no vento, porque não sabe onde que ele vai parar." (Entrevistado 3)

Sem ter o objeto (livro) como suporte para recordar ou sem tê-lo reencontrado ou relembrado em outros momentos da vida, foram mais raras as lembranças dos depoentes em rela- 
ção a autores e títulos das obras didáticas. Alguns entrevistados lembraram apenas de fragmentos:

"Eu me lembro muito bem. 0 livro didático que eu lembro era Violeta. Era o nome do livro. Era de Português. Tinha mais sobre textos. De Língua Portuguesa, histórias. Agora, depois, geralmente o grupo escolar já oferecia apostilas. Não tinha nome assim. Eles editavam naquela época.

Era isso, eu me lembro de um livrozinho, pequenino, que era sobre frações." (Entrevistado 2)

0 que se evidencia, como também apontam outros estudos, é o fato de as recordações não poderem ser confundidas com fatos do passado. São representações ressignificadas no transcorrer do diálogo presente/passado, a partir de um conjunto de lembranças selecionadas ao longo do tempo, que se tornaram significativas em um contexto mais amplo da vida do depoente. São, principalmente, memórias recortadas e reorganizadas para o interlocutor. Assim, por suas especificidades, as fontes orais precisam ser problematizadas a partir de valores e significações que estruturam as narrativas, os temas debatidos e as histórias de vida:

o realmente importante é não ser a memória apenas um depositário passivo de fatos, mas também um processo ativo de criação de significações. Assim, a utilidade específica das fontes orais para o historiador repousa não tanto em suas habilidades de preservar o passado quanto nas mudanças forjadas pela memória. Estas modificações revelam o esforço dos narradores em buscar sentido no passado e dar forma às suas vidas, e coletar a entrevista e a narração em seu contexto histórico. (Portelli, 1997, p. 33.)

Por exemplo, um dos depoentes, com a seleção de acontecimentos, lugares e personagens, ampliando o tema de sua fala para abarcar o cotidiano da escola, tenta explicar seus principios para uma escola ideal (já que se estava falando de um objeto escolar), e como ela estava atrelada a uma política educacional. Discorreu, assim, sobre outro assunto, fugindo do tema central que lhe foi solicitado lembrar, sem contudo deixar de apresentar um quadro mais amplo de valores onde pode ser identificado também o papel do livro didático no conjunto da vivência educacional.

"Uma coisa que eu lembro também da escola, posso falar também do dentista? Que tinha dentista? Então, essa escola Ildefonso, a gente... tinha dentista, só que em vez de ficar nessa escola, ficava em outra escola, Rui Barbosa, que era uma escola de material... porque a escola lldefonso eram galpões imensos compridos, cheios de salas, de madeira, que é do tempo do Brizola. Eram todas as escolas assim, compridas, as escolas primárias eram todas compridas, de galpões. E as escolas antigas, que tinham primário, ginásio e científico, eram de material, tipo Júlio de Castilho, Rui Barbosa. Então, o dentista ficava na escola Rui Barbosa. Era pertinho, umas duzentas... uns duzentos metros dessa escola. Então ficava aqui, Ildefonso no meio, que era uma escola nova do Brizola da década de 1960 , que era só os galpões de madeira. Do lado dessa escola primária ficava o Júlio de Castilho, que era uma escola grande, imensa, que só tinha ginásio e científico. E a duzentos metros dessa escola ficava o Rui Barbosa, que também era uma escola grande que tinha ginásio, científico e primário. E aí a gente ia, os alunos dessa escola, do lldefonso, eram.. o dentista, médico, ia direto. Se estava com dor de dente ia no dentista... (...) Tinha médico o dia inteiro, plantão. Não precisava ir ao posto de saúde. A própria escola tinha tudo. Ela dava merenda, médio, dentista, uniforme, se você fosse pobre. Quando eu fui morar com minha tia, já não era pobre." (Entrevistado 5)

No contexto de um depoimento como esse, vale questionar como a construção da nar- 
rativa oral interfere no sentido atribuído ao livro didático? E como o sentido para a escola interfere no significado organizado para esses materiais e na seleção de memórias? Se a memória valoriza a escola, o livro didático também é valorizado?

A resposta pode ser identificada neste outro trecho do mesmo depoimento. Nele, o entrevistado ressalta novamente o valor da escola, apresentada como uma instituição que atendia às necessidades de crianças sem recursos para obter material e que precisavam de assistência, em geral, para estudar. E, na seqüência, quando solicitado, descreve um livro sobre a história do Rio Grande do Sul como uma boa lembrança:

\footnotetext{
"Da escola primária eu lembro o seguinte: quando eu fui começar estudar no primário, você era pobre, eles davam uniforme, davam caderno, todo o material era gratuito, para pessoas pobres. E como você era estudante, você não precisava de passe. Você com uniforme de estudante não pagava condução. Eu me lembro que eu pegava ônibus. (e material didático?) Eu fui só ler livro didático, eu me lembro no terceiro ano que era livro... era mais livro do Rio Grande do Sul. Era de uma família chegando de navio em Porto Alegre, atravessando a ponte do Guaíba. Depois eles iam contando a história dessa família, e aí misturam muito sacipererê, com o negrinho do pastoreio. Negrinho do pastoreio, a história é de lá, né? Tem a bruxa..., como é a bruxa? É a lenda de uma bruxa, da serra, uma história do sul. Ensinaram muito... A maior parte é história do Rio Grande do Sul.” (Entrevistado 5)
}

Como em outros estudos, confrontamos com uma outra particularidade da história oral quando os depoimentos extrapolam o tema pesquisado, mesmo que exista um grande esforço do pesquisador em orientar as questões. A memória por ser associativa e relacional faz com que surjam lembranças variadas, de contextos amplos, ambientes e espaços, objetos, sentimentos e acontecimentos associados ao tema central. Analisados de modo amplo, porém, as recordações diversas fazem parte de um conjunto de valores e sentidos (individuais e coletivos), dos quais não escapam os que são atribuídos, por exemplo, ao livro didático.

Muito do que os depoentes recordam extrapola o foco da pesquisa. Lembram da merenda, das dificuldades enfrentadas, da professora, do recreio, dos castigos, do espaço físico da escola, dos textos literários, dos desfiles e festas cívicas, da distribuição de materiais e livros aos mais pobres, das repetências e prêmios, e dos modelos de escola (regular, multisseriada, supletiva...).

Há em alguns depoimentos a presença da escola como um espaço que atendia populações mais pobres, cedendo materiais escolares para quem não podia comprar, fornecendo sopas e merendas para crianças que lembram da fome... Isso coincide com o fato de os entrevistados, que assim relatam, terem estudado em escolas públicas. Divergem, por exemplo, do entrevistado que estudou em um seminário de padres, pago pela família. E diverge do depoimento de uma das depoentes que estudou em escola pública, mas sua família teve sempre que se encarregar da compra de seus livros escolares.

Entre outros temas rememorados espontaneamente, há nos depoimentos lembranças das repetências, sem consciência plena do que acontecia para permanecer na mesma série; ou a permanência por falta de escolas para continuidade dos estudos, como no interior da Bahia, multisseriada, na qual a criança, mesmo tendo terminado as quatro séries, permanecia na escola primária só para continuar estudando.

\section{Materialidades e usos dos livros didáticos}

Especificamente sobre livros didáticos, as entrevistas possibilitam, de modo geral, reflexões sobre a história da literatura didática no Brasil. A partir delas é possível dizer, por exemplo, que, apesar de fragmentadas as memórias, o livro esteve presente efetivamente no coti-diano da escola e há indicações de como era utilizado por 
professores e alunos. Além disso, nas recordações há relatos que identificam o que tem marcado o imaginário dos indivíduos sobre o tema, quais livros ficaram na memória de gerações, a relação entre livros e currículos (o que era estudado), a disciplina imposta no ato de ler, a presença de livros com história regional e local, os formatos e modelos de livros didáticos (capa dura, pequenos, com gravuras...), seus aspectos físicos (cor, grossura, capa...), ilustrações, mapas, quadros e atividades marcantes, etc.

Apesar de mais raras, algumas lembranças incluem a recordação dos autores por disciplinas, indicando, por exemplo, um mesmo autor - Aroldo de Azevedo - presente em escolas, locais e tempos diferentes. No caso, os depoimentos referem-se ao sertão do Rio Grande do Norte na década de 1940; e ao interior de São Paulo, na década de 1950:

"Eram três ou quatro livros básicos. 0 livro de Geografia era Aroldo de Azevedo; História era Rocha Pombo; Aritmética era de um professor de Mossoró, Sollon; o resto era editora Vozes, de Petrópolis. Latim era um livro de gramática. Basicamente era gramática. A língua era o mais fácil de aprender no seminário. Aprendia Latim e aí falava Francês e ltaliano." (Entrevistado 1)

“Os meus livros de Matemática eram do Osvaldo Sangiorgi. (...) Aroldo de Azevedo, de Geografia, Joaquim Silva, de História; de Português eu acho que não tinha livro, tinha gramática e a gente fazia redação toda semana, isso me lembro muito bem. Mas isso foi um só professor, não tive um professor só de português. Livro de Português? É acho que não tive livro de Português. Acho que tive gramática.” (Entrevistado 3)

Através da solicitação de recordações sobre os livros, têm sido identificados, nas memórias dos alunos, os nomes das disciplinas e as mudanças que elas sofreram com o tempo. É o caso da matemática que aparece como aritmética. 0 livro estudado era o livro de Aritmética.
"Era isso, eu me lembro de um livrozinho, pequenino, que era sobre frações. Hoje a molecada na boca, na memória não faz. Somar, multiplicar, dividir. Só sobre frações. A vantagem que tinha na época é que esse livrinho era usado três anos. Matemática, não era matemática. Era aritmética." (Entrevistado 2)

Alguns entrevistados lembram de livros adotados que permaneciam ao longo das séries e outros que continham, numa só publicação, muitas disciplinas. As duas lembranças coletadas referem-se ao ensino primário.

"Esse livro tinha tudo. Era um livro para tudo. Dentro desse livro tinha geografia do Rio Grande do Sul, história do Rio Grande do Sul, e português. Matemática não tinha, era separado. $\mathrm{Na} 4^{\text {a }}$ série, eu tinha um livro de religião. Isso eu lembro, eu tinha um livro só de aula de religião, que era no sábado." (Entrevistado 5)

"Ele tinha lições e exercícios de todas as matérias. Ele era quadradão assim, horizontal, tinha tamanho de um caderno universitário, mas na horizontal. Era como os cadernos de desenho de cartografia que tinha aquele formato. Era um brochurão assim e tinha todas as matérias em seqüência e tinha o texto da questão, pergunta, e espaço para você responder.” (Entrevistado 3)

Há também referências aos modos de aquisição dos livros, que variavam em função da condição social do aluno, do contexto da época e das políticas educacionais:

"0 livro durava três ou quatro séries. Livro nem comprei, ganhei. Minha tia pegou emprestado de quem já tinha cursado." (Entrevistado 5) "0 livro não pertencia a gente. 0 que eu tirava para estudar, tinha que tomar conta dele. Um livro durava dois, três anos. Livro era uma coisa rara, não era fácil não." (Entrevistado 1) 
"É... a escola dava a lista e a gente ia na livraria, comprava e passava de irmão para irmão." (Entrevistado 3)

Como explica Pierre Nora, entre as inúmeras especificidades da memória, ela "se enraíza no concreto, no espaço, no gesto, na imagem, no objeto" (1993, p. 9). Dessa forma, os livros também são lembrados por suas materialidades (como seus aspectos físicos cor, grossura, capa dura, etc.), pelas disciplinas a que se referem (português, história, admissão, etc.) e por terem formatos distintos de acordo com a série:

"O livro de geografia era um livro pequeno, capa dura. Os mapas eram todos de bico de pena, preto-e-branco." (Entrevistado 1)

"E eu me lembro muito bem da escola, da cartilha tinha uma menina de trança desenhada na capa, não era foto (...) E aí em outubro a gente recebia o primeiro livro de leitura. Desse eu tenho uma vaga lembrança dele... não sei se era da mesma autora ou não. As gravuras eram geralmente bico de pena, não eram fotografias e não eram coloridas. Mesmo os do ginásio, que depois você me perguntou, das gravuras. 0 livro de ciências era bastante ilustrado, mas geralmente com desenhos mesmo, que eram feitos com nanquim e depois para editar e tudo. E a gente não tinha essa coisa de livro colorido de fotografia, nada assim.

(...) Então do primário para o ginásio notei essa diferença dos livros. Um é capa dura, parecia livro de adulto e a gente tinha uma certa veneração com os livros.” (Entrevistado 3)

Há lembranças de imagens específicas e do estilo das ilustrações:

"O livro de História Sagrada trazia sugestões. Por exemplo: uma figura que ocupava uma página inteira, em bico de pena, era a fuga de José, do Egito. As imagens sagradas dos livros didáticos se transformavam em painéis do artesanato popular." (Entrevistado 1)
“Essa era preto-e-branco... a história de uma família chegando em Porto Alegre, num navio, pelo Guaíba. Então era a família, você via o navio, a família no convés do navio, Porto Alegre e a ponte.” (Entrevistado 5)

Alguns depoentes lembram das editoras responsáveis por produzir os livros, distinguindo por sua produção editorial:

"Os livros da Vozes, de Petrópolis, eram diferentes. Eram compridos, com papel bom. 0 de aritmética era feito muito artesanalmente.” (Entrevistado 1)

“(...) de francês era Le Français par méthode directe [C. Robin, Libraire Hachette]. Deixa eu ver se eu lembro qual era o autor. Eu tenho os livros até hoje (...) Esses livros eram os únicos que eram coloridos, esses de francês, os únicos. Eram livros importados, deviam ser caros mesmo, a editora Hachette, eles tinham situações desenhadas e pintadas e fotografadas em colorido. (...) Eu não me lembro direito das editoras dos outros, das editoras não. Esse eu acho que era uma coisa que você tinha que procurar mais pra achar, que era um nome muito diferente dos livros das outras matérias. 0 de inglês eu estou até vendo a capinha dele na minha frente. Ele era todo ilustrado, talvez ele fosse importado também, mas ele era tudo com bico de pena também. Tinha poucas ilustrações e com bico de pena, como o de francês. E o volume era bem menor, o tamanho também menor." (Entrevistado 3)

Nas lembranças, são freqüentes as recordações de como os livros eram utilizados e quais eram os métodos de ensino:

"A alfabetização foi com uma cartilha. Posso descrever: cinqüenta, sessenta páginas, tamanho Almanaque Capivarol. Começava com o abecedário, seguia a separação de vogais e consoantes. Em seguida, entrava na formação de fonemas. Era decorativo e 
muito exercício de assinar o nome, ferrar o nome. (...)

No final da aula, a classe inteira ficava de pé diante da professora. Ela ficava lá no lugar dela, como se fosse um maestro, segurando na mão direita um instrumento para reger o grupo. Normalmente, era uma palmatória. Aí, a classe inteira, quando ela dava o sinal, cantava: B e um A, BA; B e um E, BE... As mães ouviam da rua e sabiam que a aula estava acabando.” (Entrevistado 1)

“Tinha a professora de português... não, essa era a área geral. Quando faltava as outras, ela substituía. Maria Luíza Fernandes. Era muito dedicada, muito educada. Ela tinha um carisma diferente para cativar os alunos. Era diferente também porque ela fazia grupinhos para estudar, entende. Separava em grupinho para estudar. Ela ensinava mesmo. E depois tomava as lições. Ensinava tudo. Era geral. Era substituta. Quando faltava qualquer professora, de qualquer matéria, ela dava.... A gente captava melhor o ensino dela do que das outras. Como o método de ensino, né, cada uma tem diferente uma das outras. 0 método das outras, era rápido e rasteiro, como dizia antes. Rápido.... E após... ela largava o estudo e depois tomava a lição em separado. Se o aluno tivesse algum problema, então ela voltava ensinava outra vez, voltava até ensinar... É só o que eu sei." (Entrevistado 2)

Uma entrevistada distingue em suas memórias, por exemplo, o primário e o ginásio, através do método de estudo proposto pelo professor e do uso do livro ao longo das séries:

"Ah!, sim, cada professor de uma matéria, que era a grande diferença. Você tinha um professor só pra tudo e de repente... e acabava dando tudo com o mesmo jeitão... e aí de repente você ia pro ginásio e tinha cada professor com seu jeito, suas manias, suas exigências e também com seu material didático diferenciado. E então eles passa- vam, usavam também o... Não trabalhavam o livro... com a gente na classe nunca trabalhavam. Eu não me lembro de nenhum que trabalhasse com a gente, por exemplo, lendo, discutindo um texto, nunca. As aulas eles expunham, punham coisas na lousa, a gente anotava, e eles marcavam capítulos do livro pra gente estudar, responder questionários e... ou para estudar pra prova. Então você utilizava o livro sempre fora da escola, não é. Utilizava o livro mais em casa mesmo, pra fazer as tarefas, que eram muitas, a gente tinha muita tarefa, de todas as matérias." (Entrevistado 3)

Entre os livros que emergem da memória dos depoentes há livros de literatura, lidos, segundo eles, por solicitação da escola. A partir dessas indicações é possível investigar se alguns dos autores e títulos foram consagrados como literatura escolar entre gerações, presentes em diferentes regiões do país, ou apenas em certas escolas. Além disso, como as lembranças misturam as épocas, há sempre a possibilidade de essa literatura ter sido lida, mas não para trabalhos escolares:

"Isso aí, eu li um livro chamado..., gostei muito, só não sei quem escreveu, eu lembro que era Pérolas esparsas, só não sei quem escreveu. Era dessa grossura.” (Entrevistado 2)

"Foi no seminário onde eu li mais livro de aventura. Um escritor alemão, Karl May, tinha livros de aventuras no Oriente e entre os índios na América. Era leitura recomendada, que se ajustava ao contexto de estudo da gente." (Entrevistado 1)

Até algumas décadas atrás havia o que se chamava de livros de leitura. Eram livros de histórias, de moral ou de literatura, lidos em voz alta, que tinham depois seu texto explorado pelo professor. Na memória de uma das depoentes, o livro de leitura é recordado como sendo material que solicitava - e, ao mesmo tempo, disciplinava - uma postura física correta do corpo para se ler: 
"Lembro... a gente fazia leitura silenciosa, depois procurava a palavra no vocabulário se não soubesse, aí ela fazia... uma leitura oral de modelo e aí fazia uma leitura oral que ela mandava alguém ler e depois mandava outro continuar, mandava outro continuar...

[fazendo os gestos] A gente tinha que ficar de pé, segurar o livro com a mão esquerda, folhear com a mão direita. Segurar o livro com a mão esquerda assim, com os quatro dedos você apoiava o livro assim, e com o polegar você sustentava assim. E quando você tinha que virar a página, você tinha que pegar a página aqui do alto com a mão direita e virar o livro. Então era essa coisa de você ficar prestando muita atenção, porque ela falava fulano continua. E aí ela corrigia e esse negócio das vírgulas, assim você lê com pontuação. E isso era trabalhado mesmo, e era com o texto de livro de leitura. Eu não me lembro muito de ela ficar explorando muito o conteúdo, de problematizar o que a gente... isso não me lembro.” (Entrevistado 3)

0 livro de leitura geralmente era diferente das cartilhas e dos demais livros didáticos. Tinha outra organização interna e outras proposições. Uma das depoentes lembra que era diferente por não conter exercícios, mas apenas textos e vocabulário. Nesse caso específico, isso tornava o livro de leitura dependente do trabalho e da proposição do professor. Todavia, isso podia não ocorrer com outros livros do gênero, que podiam ter outras propostas de atividades escolares:

"Era diferente da cartilha. Não tinha mais aquela coisa da silabação. Ele tinha assim uma gravurinha, mesmo que em branco-epreto, tinha um texto assim que a gente gostava de ler. Geralmente, era com alguma fábula, algum conto assim, muitos tinham uma moral da história, e aí tinha um vocabulário com as palavras mais difíceis, que eles já previam que não eram usuais, e geralmente a gente precisava mesmo do vocabulário porque até as professoras precisavam entrar com outra coisa de vocabulário porque às vezes tinham muitas palavras que não eram do universo da gente e tal. E... mas eles não tinham aquele negócio de questionário, nada. Então era diferente porque a única ajudinha que tinha didática era aquele vocabulário ali.” (Entrevistado 3)

0 contato com o livro podia não ser direto. Uma depoente recorda, por exemplo, que uma professora costumava ler e desenvolver atividades a partir de um livro que era seu: Fábulas, de Monteiro Lobato utilizadas como material didático. Os alunos ouviam as leituras, recriavam os textos, mas o livro pertencia ao professor:

"E quando a gente, às vezes, não tinha o livro texto, teve série que não teve livro texto, mas ela trabalhava com reprodução. Ai ela tinha um livro, por exemplo, Fábulas, do Monteiro Lobato. Aí ela lia a fábula, a gente fazia reprodução... [copiava?] Copiava não, a gente escrevia o que ela tinha lido a história [Ditava?] Não, a gente lembrava da história. Ela lia a história, conversava com a gente sobre a história, sobre a moral da história, trabalhava um vocabulário, uma palavra mais difícil de escrever e tal e aí a gente fazia a reprodução. A gente de memória, pela exploração que tinha sido feita, você recontava a história que você tinha ouvido. Aí você ficava com um texto no caderno e às vezes ela corrigia, recolhia, corrigia... então um outro contato com o texto era assim. Um livro que era da professora, que a gente via na mão dela, que via ela lendo (...)." (Entrevistado 3)

Nas lembranças, há indicações de usos de livros com conteúdos ligados à história regional:

“A gente estava no primário inteiro só o Rio Grande do Sul. Geografia era só Rio Grande do Sul. A esse livro... era até a $4^{\mathrm{a}}$, porque tinha geografia do Rio Grande do Sul, história 
do Rio Grande do Sul, que era a revolução Farroupilha, só essas coisas. Ai tinha língua portuguesa, que trabalhava com aqueles textos lá. E matemática não tinha. Lembro que a professora de matemática de primário, ela dava matemática sem o livro." (Entrevistado 5)

Há recordações antigas, referentes à década de 1950, de situações em que o livro era substituído por apostilas, provavelmente criadas ou organizadas pelo professor. E ficaram marcadas as situações em que professores, na década de 1970, não utilizavam livros didáticos e nem apostilas. Preferiam propor para os alunos perguntas que deveriam ser pesquisadas:

"Ela fazia um questionário de cem perguntas e mandava todo mundo copiar. Ai você copiava aquele questionário de cem perguntas. E aí você tinha que responder aquele questionário. Aí ela indicava onde estavam os livros e como achar, tal, e você tinha que pesquisar e responder as cem perguntas." (Entrevistado 5)

Mudando de perspectiva, uma depoente relembrou o uso do livro como professora. Seu depoimento aponta, por exemplo, a importância de investigar como, ao longo do tempo, e, dependendo das concepções pedagógicas, esse uso torna-se variável, com justificativas e sentidos de trabalhos pedagógicos distintos. $\mathrm{Ou}$, ainda, se há permanências ao longo do tempo:

"Eu sempre tive dificuldade de usar um só, usar um só. Mas eu sempre achei muito importante recorrer a livro didático. Geralmente utilizava pra uma coisa, introduzia outras. No primário, por exemplo, minha experiência foi mais de pegar o que o MEC mandava pra escola, porque as crianças não podiam comprar. E de lá eu selecionava, o que eu queria usar de um, do outro, e completava com coisas que eu pegava de outros livros e reproduzia.... Agora, na escola normal, eu... gostava de adotar coletânea, justamente porque você trabalha com artigos que aprofundam coisas, que é difícil um autor, por exemplo, dominar com a mesma profundidade tudo. E então eu gostava de indicar pros alunos coletâneas ou então trabalhar também assim diversos livros e a gente providenciar que uma turma comprasse um, outra turma comprasse outro, depois rodava, que nem história da educação eu fiz um pouco isso. Eu fazia também alguns resumos pra eles, pra reproduzir alguns trechos, ia quebrando o galho. E também isso foi década de 1960, e como eu fui efetivada em 1970, começo de 1970 que eu trabalhei na escola normal, também não tinha tanta facilidade pra livro também. Acho que de 1980 pra cá é que melhorou bastante o preço e a variedade dos livros." (Entrevistado 3)

Nas últimas décadas, como apontam alguns autores como Marisa Bonazzi e Umberto Eco (1980), Kazumi Munakata (1998) e Eduardo Portela (2003), os livros didáticos têm sido muito criticados por educadores. E isso pode, de algum modo, interferir nos depoimentos, independentemente do uso que dele tem sido feito em outras épocas. 0 presente acomoda o passado e o transforma. Assim, esperamos avaliar até que ponto os relatos de professores podem nos aproximar do cotidiano escolar de tempos atrás e refletir sobre como os valores atuais podem remodelar a memória. Como analisa Maurice Halbwachs, há um exercício de análise importante para discernir as camadas das lembranças, sobrepostas pelas vivências sociais e pelo tempo.

A imagem que fiz de meu pai, desde que eu o conheci, não parou de evoluir, não somente porque, durante sua vida, as lembranças se juntaram às lembranças: mas eu mesmo mudei, isto é, meu ponto de vista se deslocou, porque eu ocupava dentro de minha família um lugar diferente e sobretudo porque fazia parte de outros meios. (Halbawachs, 1990, p. 74) 


\section{Referências bibliográficas}

BITTENCOURT, C. M. F. Livro didático e conhecimento histórico. 1993. 369p. Tese (Doutorado)- Faculdade de Filosofia, Letras e Ciências Humanas da Universidade de São Paulo, São Paulo, 1993.

BONAZZI, M.; ECO, U. Mentiras que Parecem verdades. São Paulo: Summus, 1980.

FERNANDES, A. T. de C. Memórias de ofícios: história dos artesãos em São Paulo. 1997. 221p. Tese (Doutorado)- Faculdade de Filosofia, Letras e Ciências Humanas da Universidade de São Paulo, São Paulo, 1997.

Memória do livro didático. In: ENCONTRO NACIONAL DE HISTÓRIA ORAL: Tempo e Narrativa, 6., São Paulo: ABHO, Departamento de História da FFLCH-USP, 28 a 31 de maio de 2002 (CDROM - ABHO/USP/CNPq).

FERREIRA, M. de M.; AMADO, J. (Org.). Usos e abusos da história oral. 5. ed., Rio de Janeiro: Editora FGV, 2002.

HALBWACHS, M. A memória coletiva. São Paulo: Vértice, Editora Revista dos Tribunais, 1990.

MUNAKATA, K. História que os livros didáticos contam, depois que acabou a ditadura militar. In: FREITAS, M. C. (Org.) Historiografia brasileira em perspectiva. São Paulo: Contexto, 1998, p. 271 - 296.

NORA, P. Entre memória e história: a problemática dos lugares. Tradução de Yara Aun Khoury. Revista do Programa de Estudos Pós-Graduados em História e do Departamento de História da PUC-SP. (Projeto História: História e Cultura). São Paulo, n.10, dez.1993.

PORTELA, E. (Org.) Reflexões sobre os caminhos do livro. São Paulo: UNESCO, Moderna, 2003.

PORTELLI, A. Sonhos ucrônicos: memórias e possíveis mundos dos trabalhadores. Tradução de Maria Theezinha Janine Ribeiro. Revista do Programa de Estudos Pós-Graduados em História e do Departamento de História da PUC-SP. (Projeto História: História e Cultura) São Paulo, n. 10, dez. 1993, p. 41-58.

. 0 que faz a história oral diferente. Revista do Programa de Estudos Pós-Graduados em História e do Departamento de História da PUC-SP. (Projeto História: Cultura e Representação) São Paulo, n. 14, fev.1997, p. 25-39.

THOMPSON, P. A voz do passado: história oral. Rio de Janeiro: Paz e Terra, 1992.

Recebido em 05.10 .04

Aprovado em 18.11 .04

Antonia Terra de Calazans Fernandes é doutora em História Social pela FFLCH da USP, professora do Departamento de História do UNIFIEO, de Osasco, e professora eventual do Departamento de História da PUC-SP. 